\title{
FROM PROTEST TO POLITICAL PARTIES: ONLINE DELIBERATION IN NEW PARTIES IN SPAIN
}

\section{Rosa Borge Bravo :: Eduardo Santamarina Sáez}

IZVORNI ZNANSTVENI RAD / DOI: 10.20901/ms.7.14.8 / PRIMLJENO: 29.02.2016.

ABSTRACT The new parties that emerged following the 15-M movement and against the austerity measures in Spain want to build parties open to the participation and deliberation for all the citizenry. To what extent are these ideals being fulfilled? The aim of this article is to describe and assess some of the main online deliberative processes of the two most important parties, Podemos and Barcelona En Comú, following commonly accepted criteria in the literature for measuring online deliberation. Specifically, we have examined the two most-voted proposals from the online platform Plaza Podemos and the online development of the electoral programme of Barcelona En Comú. Thus, we have conducted a content analysis of 713 (Plaza Podemos) and 563 (Barcelona En Comú) posts. Both platforms meet the structural and technical criteria for fostering deliberation, but the external impact is high only in the case of Barcelona En Comú. The deliberative quality of the communication is good but not the criteria of reflexivity, inclusion and plurality.

KEY WORDS

ONLINE DELIBERATION, DELIBERATIVE CRITERIA, 15-M, PODEMOS, BARCELONA EN COMÚ, SPAIN

Authors Note

Rosa Borge Bravo :: Faculty of Law and Political Science, Open University of Catalonia, Barcelona, Spain :: rborge@uoc.edu

Eduardo Santamarina Sáez :: Independent researcher, Barcelona, Spain :: esantamarina@gmail.com

This article is a revised version of a preliminary paper entitled "From protest to political parties: online deliberation in new parties arising in Spain" presented at the Fòrum Rosa Virós, Ernest Lluch Centre, UIMP, Barcelona, Spain, 4 June, 2015. 


\section{INTRODUCTION}

The $15-\mathrm{M}$ movement ${ }^{1}$ and its political offshoots, such as Podemos or Barcelona En Comú, seek a more participatory and deliberative model of democracy than the extant representative model. In many cases, the participatory and deliberative practices implemented within these new parties had been previously deployed during the protest cycle started in 2011, and continue to play an important role in the model of democracy these parties envisage for the political system ${ }^{2}$. Both parties and their varied coalitions have gained important electoral representation in Spain at the local, regional, state and European level.

However, to what extent are these new parties meeting these deliberative ideals? The main objective of this paper is to describe and assess some of the deliberative practices of the two main parties that emerged from the 15-M movement, Podemos and Barcelona En Comú, following the framework of the deliberative model of democracy and its corresponding criteria that have been developed by relevant political scientists (Dahlberg, 2004; Dahlgren, 2005; Stromer-Galley, 2007; Hendriks et al., 2007; Steiner, 2012; Kies, 2010; Friess and Eilders, 2014; Klinger and Russmann, 2014). Specifically, we have analysed the two proposals most voted on from the online platform Plaza Podemos and the online development of the electoral programme of Barcelona En Comú. All in all, a content analysis of 713 (from Plaza Podemos) and 563 (from Barcelona En Comú) posts was carried out.

Although in the last decade several studies have examined empirically online deliberation processes with political content or within political institutions (Steenberger et al., 2003; Hendriks et al., 2007; Zhou et al., 2008; Standberg and Berg, 2013; Klinger and Russmann, 2014), very few have focused on intra-party, online, deliberative processes (Kies, 2010).

It is important to consider that, in many cases, the transformation from social movement to political party has led to the restriction of the original ideals of inclusion, openness and deliberation for the sake of organisational efficiency and electoral competition (Goldstone, 2003). Also, applying deliberative ideals can create friction with principles such as participation and equality (Fishkin, 2011). Along these lines, another aim of the paper is to ascertain if this evolution could have affected the development and quality of the two parties' online deliberative processes.

The outline of the paper is as follows: first, the most important criteria for analysing the deliberative capacity of online forums is set out; second, the relevance of the two parties in studying participatory and deliberative processes is explained; next, deliberative criteria are applied to the assessment of the deliberative capacity of two debates held on the

\footnotetext{
${ }^{1}$ Also known as Indignados.

2 By way of example, the local governments of Barcelona and Madrid, headed by Barcelona En Comú and Ahora Madrid have launched two online platforms, Decidim Barcelona, Decide Madrid, for participation and deliberation based on technical devices and principles similar to those used for internal processes.
} 
main online deliberative space of Podemos, the so-called Plaza Podemos, and the process to draw up the municipal electoral programme of Barcelona En Comú. Lastly, there is a discussion of results, followed by a conclusion.

\section{ONLINE DELIBERATION AND ITS EMPIRICAL CRITERIA}

In order to evaluate the deliberative capacity of the forums launched by the two parties, we apply the widely acknowledged criteria from the literature on online deliberation. Most authors pinpoint that there are three levels that should be considered to assess the deliberative capacity of online tools (Dahlgren, 2005; Wessler, 2008; Kies, 2010; Friess and Eilders, 2014): 1) the institutional or technical dimension; 2) interactive or communicative traits; and 3) collective and individual outcomes or the impact of the deliberative process. The most common criteria for every dimension will be drawn from the literature, taking into account that, while different criteria systems have been applied empirically (StromerGalley, 2007; Kies 2010; Steiner, 2012; Klinger and Russmann, 2014; Friess and Eilders 2014), many times authors have used different labels for the same criterion or principle. Therefore, in general we will follow the criteria systems developed by Raphaël Kies (2010) and Dennis Friess and Christiane Eilders (2014), as they have sufficiently integrated the criteria of previous studies.

Below is an explanation of each dimension, the meaning of the related criteria and how they can be operationalised.

\section{The institutional or structural dimension}

This dimension refers to how online spaces should be structured to foster deliberation (Friess and Eilders, 2014: 6, 15). There are several institutional and technical characteristics that must be taken into account, such as inclusion (Kies, 2010: 42-44), asynchronous communication, content visibility, moderation, identity, division of labour into smaller units, relevant information and horizontal interaction (Friess and Eilders, 2014: 6-8).

The criterion of inclusion means that all those who are affected by and/or interested in the issues under discussion should be able to participate (Kies, 2010: 42). Thus, inclusion should be assessed by observing the ease of access in terms of connectivity and ICT skills, and by observing discursive rules such as moderation, registration and identification that should not be perceived as barriers (Kies, 2010: 56).

In addition, an asynchronous communication space is needed to allow participants to spend time reflecting and justifying their contributions (Friess and Eilders, 2014: 6-8). User content should appear immediately to motivate contributions. Moderation is also crucial to ensure deliberation in terms of civility and rationality, and for promoting inclusive participation and good organisation of the discussion. Furthermore, empirical evidence shows that personal identification has positive effects on the deliberative quality of online debates. The technical design should enable a division into smaller units focused on different issues and debate areas in order to enlarge the opportunities for deliberation. 
Finally, the designed structure of the online forum should enable horizontal interaction and communication with other users.

\section{The communicative dimension}

This refers to the deliberative attitude of participants (Kies, 2010: 42) and what the communication process should look like, mainly in relation to participants' reactions to each other's ideas (Friess and Eilders, 2014: 8). Deliberation should be rational, interactive, equal and respectful. This is the core of deliberation theory's normative claims (Habermas, 1990). The most crucial feature of deliberation is rationality; that is, to state positions substantiated with arguments and empirical evidence, expecting critical exchange and diversity of arguments, and being willing to change one's own opinion in light of better arguments (Friess and Eilders, 2014: 8). Therefore, rationality involves criteria such as reciprocity, justification, reflexibility, empathy (including civility), plurality, discourse equality and sincerity (Kies, 2010: 44-54).

In the following table, we present the most important criteria that characterise whether communication in an online platform can be considered deliberative.

Table 1. The communication process in an online forum: deliberative criteria, their meaning and operationalisation

\begin{tabular}{|c|c|c|}
\hline $\begin{array}{l}\text { Deliberative } \\
\text { criteria }\end{array}$ & Meaning & Operationalisation \\
\hline $\begin{array}{l}\text { Discourse } \\
\text { equality }\end{array}$ & $\begin{array}{l}\text { Participants should have equal } \\
\text { opportunity to introduce and } \\
\text { question any assertion, and to } \\
\text { express attitudes, desires and needs. }\end{array}$ & $\begin{array}{l}\text { Analysis of discursive concentration } \\
\text { and whether this concentration leads to } \\
\text { control of the debate. }\end{array}$ \\
\hline Reciprocity & $\begin{array}{l}\text { Participants should listen and react } \\
\text { to the comments formulated by } \\
\text { other participants. }\end{array}$ & $\begin{array}{l}\text { Measured through content analysis by } \\
\text { assessing the proportion of posts that } \\
\text { are part of a thread, versus the ones } \\
\text { that initiate a thread, and by measuring } \\
\text { the extent to which posts take into } \\
\text { consideration arguments and opinions } \\
\text { of a preceding post. }\end{array}$ \\
\hline Justification & $\begin{array}{l}\text { The opinions and propositions } \\
\text { should be accompanied by } \\
\text { reasoned and accessible } \\
\text { justifications. }\end{array}$ & $\begin{array}{l}\text { Measured using content analysis by } \\
\text { observing whether opinions and } \\
\text { suggestions are justified and how } \\
\text { complex the justifications are. Analysis } \\
\text { of whether the justification's arguments } \\
\text { are internal (based on personal } \\
\text { viewpoints and values) or external } \\
\text { (based on facts, figures, links to other } \\
\text { information and evidence). }\end{array}$ \\
\hline Reflexivity & $\begin{array}{l}\text { Participants should examine } \\
\text { critically their values, assumptions, } \\
\text { and interests, as well as the larger } \\
\text { social context. }\end{array}$ & $\begin{array}{l}\text { The content analysis identifies visible } \\
\text { instances of changes in opinion, } \\
\text { conflict resolutions or participants' } \\
\text { acknowledgement of being better } \\
\text { informed after participating. }\end{array}$ \\
\hline
\end{tabular}




\begin{tabular}{|c|c|c|}
\hline $\begin{array}{l}\text { Empathy or } \\
\text { civility }\end{array}$ & $\begin{array}{l}\text { Participants should be sensitive to } \\
\text { other views and opinions. }\end{array}$ & $\begin{array}{l}\text { Measured though content analysis by } \\
\text { counting the cases of disrespect, insults } \\
\text { and wry comments. }\end{array}$ \\
\hline Sincerity & $\begin{array}{l}\text { Participants must make a sincere } \\
\text { effort to make known all relevant } \\
\text { information and their true } \\
\text { intentions and interests. }\end{array}$ & $\begin{array}{l}\text { Measurements based on content analysis } \\
\text { are: inconsistency in speech, rhetorical } \\
\text { forms of speech and complaints by other } \\
\text { participants regarding the insincerity of } \\
\text { other participants. }\end{array}$ \\
\hline Plurality & $\begin{array}{l}\text { A deliberative context should be a } \\
\text { context in which a plurality of voices } \\
\text { is heard even if those voices are } \\
\text { critical of the dominant opinions/ } \\
\text { ideologies. }\end{array}$ & $\begin{array}{l}\text { Content analysis determines the degree } \\
\text { to which the debates refer to different } \\
\text { political ideologies and whether } \\
\text { there is disagreement and conflicting } \\
\text { standpoints. The registration system, } \\
\text { if it is not anonymous, could provide } \\
\text { information about gender. }\end{array}$ \\
\hline
\end{tabular}

Source: Own adaptation based on Kies, 2010: 42, 56-57.

\section{The outcome dimension}

This dimension alludes to the results or impact of the deliberation, which could be individual or collective. At the individual level, participation in deliberative forums can contribute to increased tolerance, political knowledge and efficiency, public-spirited attitudes, willingness to compromise or a shift in preferences (Friess and Eilders, 2014: 10; Hendricks et al., 2007). At the collective level, there are benefits related to the quality of decisions such as the generation of consensual decisions or, at the very least, decisions without errors, with high epistemic qualities, as they are based on relevant reasons and evidence. Thus, the final decision will be more legitimated and supported by a wider public (Habermas, 1996; Friess and Eilders, 2014: 10).

In addition, Kies (2010: 54-55) highlights the relevance of the external impact of the deliberative process. That means that decisions resulting from online forums should have an impact on public debates and political decisions and even shape binding norms to contribute to the participation of citizens and guide official decision-making processes (Dahlberg, 2004; Hendricks et al., 2007).

The next section presents the two main parties that are the object of study. The aforementioned deliberative criteria and operationalisation, through content analysis, are applied to the assessment of two online platforms developed by the two parties.

\section{FROM SOCIAL MOVEMENT TO POLITICAL PARTIES: THE TWO PARTIES AS A CASE STUDY}

Podemos and Barcelona En Comú have clearly stated that they aim to open themselves to the participation and deliberation of all the citizenry. They have tried to reproduce the 15-M movement's structure through neighbourhood assemblies, different issue groups 
and working committees, and by giving the general assembly or plenary established in the party statutes a dominant position.

The Podemos party was officially registered three months before the 2014 European elections. Podemos entered the European Parliament with 5 MPs. In the local elections held on 24 May 2015, the citizen left-wing coalitions that included Podemos won control of the municipal governments in Madrid, Barcelona, A Coruña, Cádiz and Zaragoza. Finally, in the Spanish general elections held on 20 December 2015, Podemos obtained more than five million votes and nearly a $21 \%$ share of the votes. As a result, Podemos became the third largest political force in Spain.

The Barcelona En Comú coalition appeared in June 2014. The promoters built a new left-wing coalition for the 24 May 2015 local elections and this influenced the emergence of similar coalitions in different cities throughout Catalonia and Spain. Their leader, Ada Colau, the former spokesperson of the PAH (Platform for People Affected by Mortgages), became the first female mayor of Barcelona when Barcelona En Comú won the 2015 local elections.

In less than a year, these political formations have carried out an enormous amount of activity in order to develop participatory and deliberative processes to define their internal structure and electoral programmes, and to select candidates, leaders and executive boards. Regarding membership anybody can easily register online or offline ${ }^{3}$ as a member of the party with no fee. Party officials and electoral candidates are selected by primaries and can be removed by party member demand. Specific consultations or referendums on important decisions are established in the statutes and there are channels for individual members to issue any kind of proposal (i.e. citizen initiatives in Podemos).

Moreover, these new parties make an intensive use of new technologies. Apart from social media, such as Facebook and Twitter ${ }^{4}$, the new formations use different free online tools, such as Appgree, Agora Voting, Loomio, Reddit or DemocracyOS, for internal communication and organisation, and voting and deliberation on proposals, political issues and candidates.

The aim of this article is to assess the deliberative capacity of two relevant, online, deliberative processes taking place within Podemos and Barcelona En Comú. In the case of Podemos, we focus on Plaza Podemos (Podemos Square), the main online space for deliberation, hosted on Reddit. Reddit functions as an open and public discussion board where users can post comments and hyperlinks, and also give votes to the posts submitted. The platform enables thematic discussions organised in a tree-like arrangement of nested threads. At its peak (November 2014), Plaza Podemos received 280,000 unique visitors and more than 2.4 million page views.

\footnotetext{
${ }^{3}$ Offline registration is not currently possible in the case of Podemos.

${ }^{4}$ Podemos' party profile has more than 1 million followers on Facebook and Twitter, between seven and three times that of the two main "traditional" parties, PP and PSOE.
} 
As for Barcelona En Comú, we will analyse the online participation process in the preparation of the municipal programme, which was based on DemocracyOS. The online development of the electoral programme began with 44 priority actions divided into 4 blocks: (1) Social emergency; (2) Structural changes; (3) A more human Barcelona; and (4) Let's open up the institutions. These proposals, which had been previously drafted by the thematic committees of the organisation, were hosted on the DemocracyOS online tool. The aim of the online process was to improve the 44 priority actions and to generate new proposals which could then be voted on and receive comments.

\section{DATA AND METHODS}

We assessed the deliberative quality of these two parties' most relevant online deliberative processes by examining the three dimensions that constitute a deliberative space: the institutional, the communicative, and the outcome or impact dimensions. Following the criteria explained in previous sections, for the first dimension we ascertained how the two online platforms were structured and technically organised. For the third dimension, we determined whether the results of the debates analysed were accepted by the party.

Regarding the second, or communicative, dimension, we carried out a content analysis of three discussions. In the case of Podemos we examined two online debates, held on Plaza Podemos, that achieved a high number of votes in April 2015. The first one was about the Universal Basic Income (470 posts and 144 participants), and the second was on the improvement of the party's registration system (243 posts and 99 participants). In the case of Barcelona En Comú, we analysed the online deliberation process to prepare the municipal electoral programme, which took place from 19 February to 2 March 2015, with the participation of 181 people. In total, our content analysis examined 713 (Plaza Podemos) and 563 (Barcelona En Comú) posts.

Among the deliberative criteria analysed (see Table 1), the criterion of sincerity was not studied, as its measurement is extremely complex (Kies, 2010: 57).

The coding of the posts was double-checked. One author did all the coding, once the coding scheme had been agreed on previously with the other author. After the coding was completed, the other author randomly sampled $10 \%$ of the posts to check for consistency and inter-coder reliability. Krippendorff's alpha was $>0.8$ for reciprocity, reflexivity and civility on both platforms. In relation to justification, the figures were 0.72 for Universal Basic Income, 0.77 for the registration system and 0.81 for the Barcelona En Comú electoral programme debate. Therefore, the coding carried out was reliable. 


\section{RESULTS}

\section{Assessment of the degree of deliberation on Plaza Podemos}

First we examined the institutional dimension. Regarding Plaza Podemos' subreddit, most of the technical criteria are satisfied. The platform allows asynchronous participation by users. Conversation is open, so users can contribute with their post at any time, and user content appears immediately, allowing horizontal interaction either by commenting on other users' threads and comments or voting on their contributions. The moderation team only participates occasionally, deleting comments that contain insults or disrespectful words. The platform is subdivided into different categories and every debate refers to a specific subject, so large tasks are divided into smaller units, which usually contain relevant information concerning documents, links to explanatory videos or articles. User identification only requires a user name (or nickname) and a password: it is not necessary to introduce an email address or to be registered as a member of the party.

Regarding the third level, which refers to the outcome dimension, Plaza Podemos could theoretically have a high external impact. It regularly hosts important debates concerning the party's organisation and public policies, and allows the deliberation of proposals that could be selected to be put to a vote in a binding referendum. The objective of the debates generated in the "Proposals" section within Plaza Podemos is to find the necessary support for a proposal to be voted on as a "citizen initiative" in a binding referendum for the whole party. To achieve this, the citizen initiative should be approved in successive stages by $0.2 \%, 2 \%$ and $10 \%$ of the registered members (Podemos, 2014: 42-43). Taking into account that the number of registered members is around 350,000 people, after almost two years in operation, none of the proposals have reached the last threshold of $10 \%$ of the registered members.

With regard to the communicative dimension, we have focused on the debates generated by the two most popular proposals from Plaza Podemos, which achieved $0.2 \%$ of those registered Podemos members' votes. The first one related to the incorporation of a Universal Basic Income into the party's programme (with 833 votes), and the second one was aimed at changing the census thresholds for approving proposals (with 814 votes).

\section{Basic Income proposal}

The thread about the Universal Basic Income was posted on Plaza Podemos on 10 April 2015 by the Basic Income Circle (Plaza Podemos, 2015a). The aim of the proposal was to include the Universal Basic Income in the electoral programme for the 2015 general elections ${ }^{5}$. The Basic Income proposal, with 833 votes, generated a total of 470 posts on Plaza Podemos, divided into 146 initial threads and 324 comments.

Regarding the first criterion on discourse equality, there were 144 participants, with four users contributing more than 20 posts, amounting to a total of 119 posts ( $25 \%$ of total entries), and another 4 users contributing from 10 to 20 posts (10\% of entries). However,

\footnotetext{
$\overline{5}$ Finally, the Universal Basic Income was not included in the electoral programme because it did not reach the last threshold, that is, votes from $10 \%$ of the registered members.
} 
the rest of the posts were fairly distributed: 105 users added 1 or 2 posts $(28.5 \%$ of the posts), and 29 users generated 3 to 9 posts (34\%). The mean number of posts per user was 3.1 , with a standard deviation of 5.4 posts, showing a highly skewed distribution.

Although this situation could be viewed as discourse concentration, the most active participants made more of their contributions to conversations with a greater number of threads, in which they expressed their opposition to the proposal and different points of view. These threads generated discussions with a high level of rational thinking and civic and constructive dialogues. In any case, the concentration was lower than in other political forums examined by other authors (Kies, 2010: 125; Zhou et al., 2008: 764-765).

Figure 1 shows the levels for the other four criteria (reciprocity, justification, reflexivity and civility).

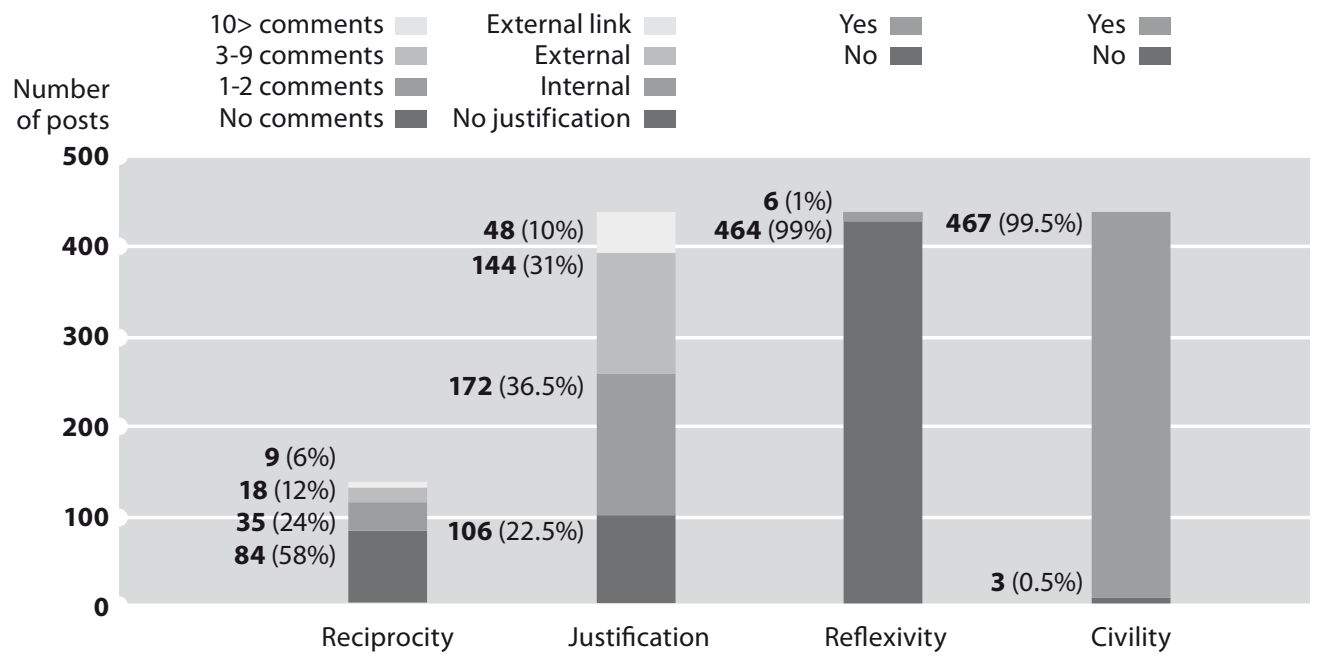

A Figure 1.

Basic Income proposal by deliberative criteria

With regard to reciprocity, of the 146 threads initiated, 35 (24\%) of them generated 1 or 2 comments, 18 (12\%) generated 3 to 9 comments, and $9(6 \%)$ incited 10 or more comments. Therefore, 62 of them (42\%) generated at least one comment and 84 (57.5\%) did not produce any comments. These figures reflect a high reciprocity level, since the reciprocity is usually lower in online political forums (Kies, 2010: 157).

As for justification, of all the entries, 364 (77\%) were justified with arguments. Most justifications - 172 (48\%) - were internal (referring to personal experiences or opinions), 
and the remaining 144 (39\%) presented arguments based on calculations and references to specific points of the proposal document. Moreover, 48 of the entries (13\%) had at least one link to external sources and articles. It is remarkable that $52 \%$ of the justifications were external and not as centred on personal experiences or anecdotes as is common in other political and non-political deliberations (Stromer-Galley, 2007: 15, 19).

Some of the participants demonstrated a broad knowledge of legal, economic and tax issues, creating a rich debate based on examples, figures and information resources. Although most of the interventions were in favour of the Universal Basic Income proposal, there were users who were against the proposal, justifying their opinion and offering different reasons.

In relation to reflexivity, only six users expressed a change or modification of their opinion about the Basic Income based on the general conversation. Regarding civility, only three comments could be considered disrespectful.

\section{The proposal to improve the registration system}

The proposal to improve the registration system and enhance real participation in Podemos (Plaza Podemos, 2015b) was based on the assumption that "many people who are registered in Podemos do not want to participate anymore, or they registered but never voted, and that negatively affects the participation of the rest". To deal with this situation, the proposal's initiator suggested that the census should be divided between active and non-active profiles during the last four months, with only the first being used to calculate the high thresholds necessary to implement processes such as citizen initiatives, revocation processes, or the call for consultations by the circles.

The proposal generated a total of 243 posts in Plaza Podemos, divided into 119 initial threads and 124 comments, and received 814 votes. With regard to discourse equality, the concentration of the discourse was not large, but higher than in the Basic Income debate. One of the users contributed 49 entries (nine threads and 40 comments) to the debate, representing $20 \%$ of total entries. Most of these entries consisted of encouraging other users to vote in favour of the proposal or announcing the number of votes received. The second user with the most comments, 15 posts ( $6 \%$ of total), was the author of the proposal, which is logical since he answered some of the questions related to the topic posed by others users. The majority of users (86\%) posted only one entry. The mean was 1.6 posts per user with a standard deviation of 3.4 posts, showing a skewed distribution due to the activity of these two key contributors. These figures also show less conversation than in the Basic Income debate.

Figure 2 on the next page shows the levels for the other criteria (reciprocity, justification, reflexivity and civility). 


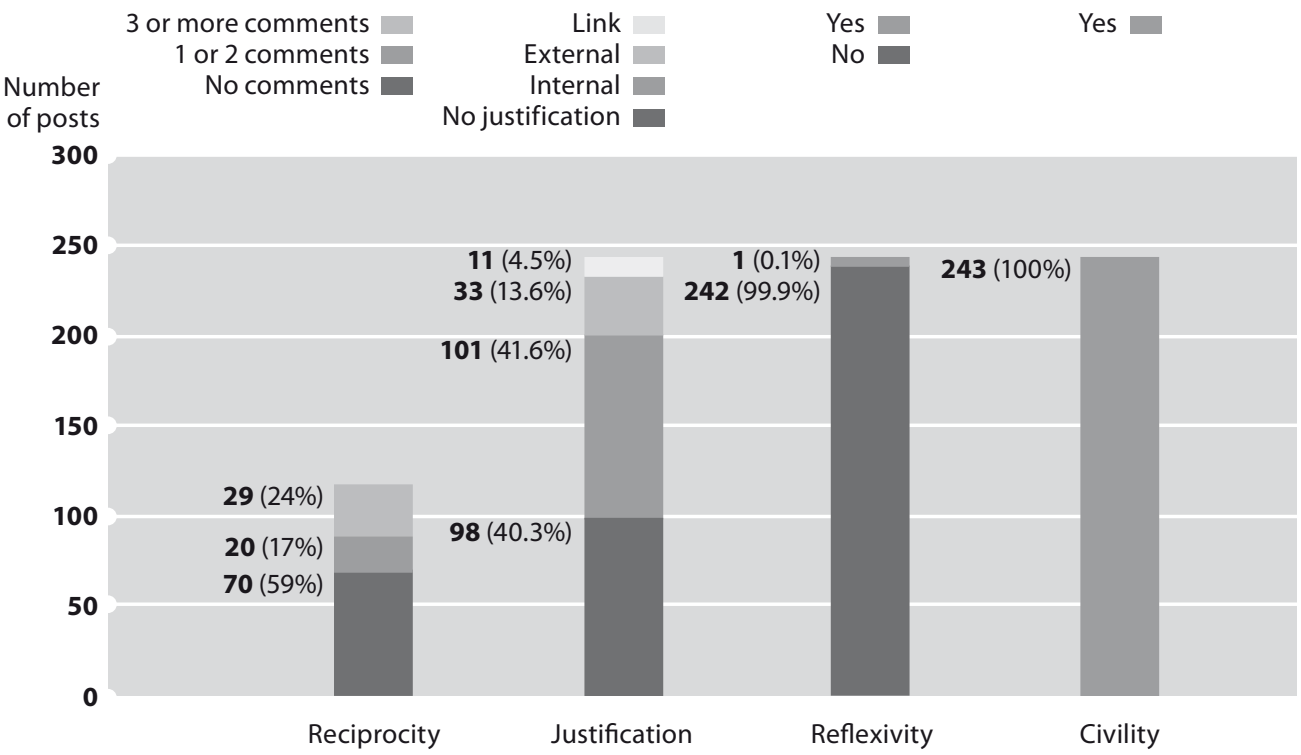

$\Delta$ Figure 2 .

Proposal to improve the registration system by deliberative criteria

In regard to reciprocity, 20 threads (16.6\%) generated one or two comments, 29 threads produced 3 or more comments (24.4\%) and 70 (59\%) did not lead to any comment. Therefore, the level of reciprocity is significant if we compare it to other online political forums (Kies, 2010: 157), although it was lower than in the case of the debate on the Basic Income.

The discussion had a high justification level. Of all the entries, 145 (60\%) were performed justifiably. The justifications were mostly internal: 101 (41.6\%) referred to personal experiences; among the remaining 44 posts, 33 (13.6\%) referred to external facts; and 11 (4.5\%) had a link to different external documents or articles. Some of the users who did not agree with the proposal, suggested other ways of improving participation, giving rise to a rich debate on the channels of participation and registration laid down by the party.

Regarding reflexivity, a user expressed a change of opinion about the proposal deciding to vote in favour of it. As for civility, the debate had no disrespectful comments. 


\section{Assessment of the degree of deliberation in the preparation of the municipal programme of Barcelona En Comú}

Barcelona En Comú's online space for the preparation of the electoral programme was divided into four thematic blocs and two areas within each block ${ }^{6}$. The first area (the amendments area) allowed annotations to be made to the previously developed document. In the second area (new proposals), located at the bottom of the document, participants could make new proposals that could then be voted on and receive comments.

In line with the framework established previously, the results of the analyses of the deliberative capacity of this process are the following:

The institutional dimension involving the structural and technological conditions was examined first. The DemocracyOS platform satisfied the conditions considered, as it allows asynchronous participation by users and the immediate appearance of the users' comments and provides horizontal interaction by allowing users to comment on other users' threads and to comment or vote on their contributions. The process had moderators who facilitated the discussions by placing the proposals or improvements in the appropriate sections, grouping together similar proposals and eliminating the comments that were repeated or offensive. The documents on the platform included highly relevant information, as they consisted of all the proposals for the electoral programme. The activity was divided into four thematic blocks, with large issues being subdivided into smaller ones. User identification was done using the name and surname of the participants.

Regarding the third dimension to test the deliberative capacity of an online forum, the process and space examined had an important external impact, since the proposals and contributions made through the platform were included (after being voted on) in the party's electoral programme.

The online process involved a total of 181 people. However, participation was skewed in terms of gender, pointing to problems of inclusion and plurality: 120 of the participants were men (77\%) and only 60 were women (33\%) ${ }^{7}$. Nevertheless, these proportions are similar to other political online deliberative settings (Kies, 2010: 128; Klinger and Russman, 2015: 476). A total of 563 entries were generated, divided into 392 initial threads and 171 comments. Regarding discourse equality, the participation of users in the conversation was fairly distributed. Although three users contributed a total of 59 posts $(10.5 \%$ of total entries), and 20 users generated from 6 to 14 comments (29.5\%), the rest of the posts were highly distributed: 83 users (46\% of total users) contributed 2 to 5 posts, amounting to almost $47 \%$ of the total entries, and 75 users raised only one comment (13\% of the posts). The mean posting rate was 2.9 posts per person, with a standard deviation of 2.9 posts, a distribution which is not as skewed as in the case of Plaza Podemos' debate.

\footnotetext{
$\overline{6}$ 1. Social emergency: http://preprograma.barcelonaencomu.cat/law/54e4ca47b690493300a94308 (07.11.2016).

2. Structural changes: http://preprograma.barcelonaencomu.cat/law/54e4d3b02d6bfa3500d369ab (07.11.2016).

3. A more human Barcelona: http://preprograma.barcelonaencomu.cat/law/54e4d5fdf455314b00718051 (07.11.2016).

4. Let's open up the institutions: http://preprograma.barcelonaencomu.cat/law/54e4d8adb690493300a9431a (07.11.2016).

${ }^{7}$ The gender of one of the users could not be determined since he/she took part on behalf of a neighbourhood group.
} 
Figure 3 shows the levels for the other criteria (reciprocity, justification, reflexivity and civility).

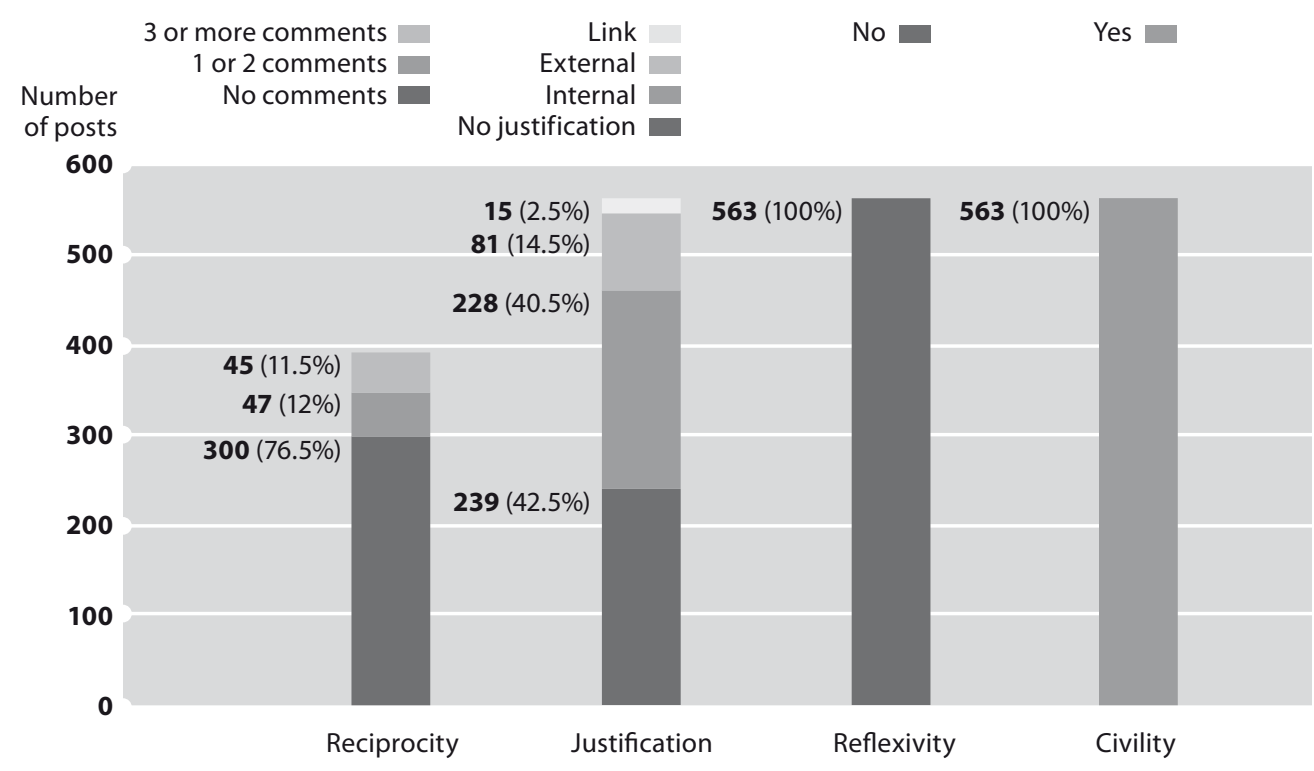

Debate on the municipal programme of Barcelona En Comú by deliberative criteria

In regard to reciprocity, of the 392 threads initiated in total (both in the amendments area and the new proposals area), 47 (12\%) of them generated one or two comments, though only 45 threads (11.5\%) generated three or more comments. Thus, 300 threads (76.5\%) did not yield any comments.

The part related to the amendment of documents generated a total of 50 threads and 73 comments. The comments were concentrated into certain specific topics that raised some doubts (i.e. the use of the feminine in the generic, the restriction of people's participation in the municipal budget to only $5 \%$ of the total budget, etc.), but none of the comments were in radical disagreement with party proposals. In the section reserved for new proposals, 342 new proposals were made, yielding 98 comments. Sixty-three proposals (18\%) generated at least one comment, most of them aimed at the extension or detail of the proposal. Therefore, reciprocity was low. Most of the threads in both areas failed to generate any comment because they either amended or clarified the proposals presented by the party or were new proposals that the rest of participants did not discuss. 
As for justification, within the area of new proposals, there were a total of 440 proposals and associated comments, but there were only 123 contributions in the amendment area. In total, 324 (57.5\%) were supported with arguments, so the process could be considered as having a high justification level. Most of these justifications - 228 (40.5\%) - were personal or internal opinions. There were also external justifications, referring to examples or cases concerning the city and its institutions - 81 (14.5\%) - or with external links to documents or websites $-15(2.5 \%)$-. Of the 98 comments addressing the new proposals, 89 of them (91\%) agreed with the proposals generated by users and were aimed at improving the proposals, indicating that the participants were more focused on contributing to the programme than on enriching the debate with different points of view.

With regard to civility, participants showed respect for the other participants, with a complete absence of incivility or insults. As for reflexivity, the number of comments opposed to the proposals made by the party or by other users was very limited and did not generate a change of opinion, indicating a low level of reflexivity. Only four of the entries stated opposing views, and participants failed to start a debate on them. Furthermore, only four proposals received negative votes, showing little disagreement.

\section{DISCUSSION}

The institutional design of both online spaces positively fulfils the majority of the structural and technical criteria for fostering deliberation. With relation to the criterion of inclusion, these two spaces perform very well at the technical level, since everyone can participate with only a full name or a nickname. Regarding the criteria of identification, on the Barcelona En Comú online space, citizens must identify themselves by name and surname, which is felt to ensure the quality of the deliberation and increased civility, while in the case of Plaza Podemos, only a nickname is needed to actively participate. The role of the moderators in the threads and proposals was not intrusive and they took part on very few occasions. Moderation, registration and identification were no barrier to promoting inclusive participation on these two spaces (Kies, 2010).

Nevertheless, with relation to registration, several problems were detected with Podemos: first, the easy online registration system has suffered several failures that have invalidated primaries, caused dismissals, and been misused on one occasion by right-wing intruders (Alvarez, 2015). Secondly, some active members (see the proposal to improve the registration system) and circles (the Basic Income Circle) have raised concerns about the weight that the huge census of registered members could have in the approval of bottom-up initiatives.

In terms of the external impact, it is theoretically high on both spaces, as the proposals with the most votes are supposed to be accepted by the party as part of the programme. A binding outcome is a significant incentive to participate and deliberate (Kies, 2010) and an important source of legitimacy for the decision-making process (Habermas, 1996). However, in the case of Podemos, until now none of the proposals have reached the 
number of votes required to be considered for a binding referendum. Notwithstanding, there are signs of some effects of the deliberations examined here (Kies, 2010: 57): only the active registered members were allowed to participate in the elaboration of Podemos' 2016 electoral programme, and this programme included a measure for a minimum income for people with earnings below the poverty threshold.

With regard to the communicative dimension, the examination of the two mostvoted proposals from Plaza Podemos shows a high level of discourse equality, reciprocity, justification and civility. Although there are repeated users that represent around 1/4 of the threads and comments, this is due to their being the initiators of the threads, and their corresponding explanations and answers to other users. Most of the conversations showed multiple sources of information based on different points of view. Possible solutions and alternatives were discussed. However, the level of reflexivity is low, as very few users expressed a change of opinion or position. Also, the content of many comments referred to the direction of their vote or to encourage other people to vote, but not so much to debate.

In the case of Barcelona in Comú's DemocracyOS platform, the majority of participants limited themselves to presenting proposals or corrections without questioning the other participants or stimulating debate among them. The process generated an "aggregative" and "competitive" activity, based on making proposals that were voted on, rather than questioning or improving them through deliberation. There is also an absence of disagreement or conflict, which often acts as a trigger for deliberation (Gutmann and Thompson, 2004). The entire situation produced a low level of reciprocity and reflexivity, although justification and civility were very high. Three institutional features could have undermined the disagreement degree and the level of deliberation of the online process: first, although the proposals were divided into blocks and sub-themes, the topics were too broad; second, the online discussion was open for only 12 days; and third, the main proposals for the municipal programme had already been discussed offline by thematic and neighbourhood groups. In the case of Plaza Podemos, the initiative was totally in the hands of the online participants.

In summary, the deliberative quality of the communication in both online forums can be considered good in terms of the generally high level of discourse equality, reciprocity, justification and civility. The discourse seems less concentrated (between two and four users concentrated around 1/4 of the comments in the case of Plaza Podemos, and only $10.5 \%$ in the case of Barcelona En Comú) than what is indicated by figures found in studies on the websites of newspapers (Zhou et al., 2008: 764-765). The level of reciprocity was high in the case of Plaza Podemos, but the online debate on Barcelona En Comú's electoral programme aroused less reciprocity, below the level of other online political forums, where around $40 \%$ of the threads received a comment (Kies, 2010: 157). Around 60\% of the posts were justified with arguments, and politeness and civility were definitively higher than on newspaper websites (Zhou et al., 2008: 766; Strandberg and Berg, 2013: 143). Usually studies of online forums show that the majority of justifications disclosed are internal (Stromer-Galley, 2007). However, the majority of arguments in Plaza Podemos' 
debate on the Universal Basic Income were external, based on figures, documents, links to videos, websites, etc.

Nevertheless, the criteria of reflexivity, inclusion and plurality (with regard to gender composition and ideological disagreement) were not sufficiently met. In any case, the lack of reflexivity and ideological plurality are typical problems for partisan forums or "enclave" deliberation which have not been specifically designed to avoid them (Gutmann and Thompson, 2004; Kies, 2010). The gender gap is similar to that found in other online political forums (Kies, 2010; Baek et al., 2012; Klinger and Russmann, 2015), where men usually represent two-thirds of participants.

In our opinion, the levels of reciprocity, reflexivity and the quality of the justification could have been undermined by a mixed-up design where the online processes are at once deliberative and participatory spaces. Proposals were being discussed and voted on at the same time. This "procedural duality" seems to have caused user contributions to lean towards the competitive voting side. For example, in the case of Plaza Podemos, a high number of participants made contributions only to communicate that they had voted in favour of the proposal or to encourage others to vote for it without providing any justification or adding content. In the case of Barcelona En Comú, posts did not reflect such fierce competition for votes, but the proposals and amendments were not discussed extensively. It possibly would have been better to separate the processes step by step following a sequential path, just as James Fishkin (2011) and Jon Elster (2013) have defended in their proposed participation in and deliberation of constitutional reforms and public policies (Balcells and Padró-Solanet, 2015). Futhermore, Fishkin (2011:248) argues that ensuring simultaneously equality, participation and deliberation at a mass level is difficult. Both online platforms did not achieve important aspects of equality, such as having similar proportions of men and women taking part, or a plurality of opinions and ideologies. Although the debates analysed from Plaza Podemos showed a broad diversity of opinions and opposing views, in the case of the elaboration of the Barcelona En Comú electoral programme, diversity of opinion was scarce.

All these problems point to the tension between openness and restriction that is typical in a new party coming from a popular movement that also faces a tight electoral schedule (Goldstone, 2003). Barcelona En Comú has promoted quick participatory processes without the required tranquillity and time for deliberation. Podemos has an easy, but not necessarily very safe online registration system that has resulted in a partially flawed census and a large numbers of inactive members.

\section{CONCLUSION}

The examination of the three dimensions of an online deliberative setting (institutional, communicative, outcome) has proven useful in assessing the deliberative quality of the debates taking place on the two parties' online platforms. Therefore, this comprehensive perspective could be applied to other cases and replicated in other online forums (Freiss and Eilders, 2014). 
The online deliberative processes taking place in Podemos and Barcelona En Comú show that if there is political will, it is technically possible to set up online party spaces that are open and self-managed by citizens on a large scale. In addition, when compared with other political deliberative settings, the deliberative quality of the communication in both online forums can be considered high or average in terms of discourse equality, reciprocity, justification and civility (Stromer-Galley, 2007; Zhou et al., 2008; Kies, 2010; Strandberg and Berg, 2013).

However, the criteria of reflexivity, inclusion and plurality (with regard to gender composition and ideological disagreement) were not satisfactorily met. Opinion shifts (reflexivity) and ideological pluralism seem to be difficult to achieve in a party forum, which is much more homogeneous than other forums such as newspaper websites or debates on local policies (Kies, 2010; Gutmann and Thompson, 2004). Also, a lack of gender equality seems to affect most online political forums around the world (Baek et al., 2012; Klinger and Russmann, 2015). Moreover, we detected certain pitfalls in the institutional design of the debates that could undermine the deliberative capacity of the processes: the fact that deliberation and voting take place at the same time; the limitation of the impact on party decision-making due to voting thresholds; or the short amount of time assigned to discussion given the electoral deadlines.

Both parties acknowledge in their internal documents that the deliberative processes deployed imply high experimentation and learning by doing, and that they could be subjected to future changes and adjustments.

Echoing Jane Mansbridge, the deliberative model of democracy is a "regulative" ideal, which "is unachievable in its full state but to which a practice should be judged as approaching more or less closely" (Steiner, 2012: 3).

\section{References}

>Alvarez, Daniel (2015) Dimisión en Podemos por votar con un censo 'de risa' [Member of Podemos Resigns after Vote Involving 'Laughable' Register]. El Mundo. https://www.elmundo.es/baleares/201 5/02/19/54e5b4d422601d18758b4572.html (19.02.2016).

>Baek, Young Min, Wojcieszak, Magdalena and Delli Carpini, Michael (2012) Online Versus Face-toface Deliberation: Who? Why? What? With what effects?. New Media \& Society 14 (3): 363-383. DOI: $10.1177 / 146144481141319191$.

>Balcells, Joan and Padró-Solanet, Abert (2015) By the People: Possibilitats i límits d'un procés constituent crowdsourced [By the People: Possibilities and Limits of a Crowdsourced Constituent Process]. Àmbits. http://ambitscolpis.com/2015/04/16/by-the-people-possibilitats-i-limits-dunproces-constituent-crowdsourced/ (19.02.2016).

>Barcelona En Comú (2014) Propuesta organizativa [Organizational Proposal] https:// guanyembarcelona.cat/wp-content/uploads/2014/06/propuesta_organizativa_cast.pdf (19.02.2016).

>Dahlberg, Lincoln (2004) The Habermasian Public Sphere: a Specification of the Idealized Conditions of Democratic Communication. Studies in Social and Political Thought 10: 2-18. >Dahlgren, Peter (2005) The Internet, Public Spheres, and Political Communication: Dispersion and Deliberation. Political Communication 22: 147-162. DOI: 10.1080/10584600590933160. 
>Elster, Jon (2013) Securities Against Misrule: Juries, Assemblies, Elections. Cambridge, MA: Cambridge University Press. DOI: 10.1017/CBO9781139382762.

>Fishkin, James S. (2011) Deliberative Democracy and Constitutions. Social Philosophy \& Policy 28: 261-260. DOI: 10.1017/S0265052510000129.

>Friess, Dennis and Eilders, Christiane (2014) Analyzing Crowd Discussion. Towards a More Complex Approach to Measure and Explain Deliberativeness Online. Paper presented at the IPP 2014 Conference, Oxford Internet Institute: Oxford. http://ipp.oii.ox.ac.uk/sites/ipp/files/documents/ IPP2014_Friess.pdf (26.02.2016).

$>$ Goldstone, Jack A. (ed.) (2003) States, Parties and Social Movements. Cambridge, MA: Cambridge University Press. DOI: $10.1017 /$ CBO9780511625466.

>Gutmann, Amy and Thompson, Dennis (2004) Why Deliberative Democracy. Princeton, NJ: Princeton University Press. DOI: 10.1515/9781400826339.

>Habermas, Jürgen (1996) Between Facts and Norms. Contributions to a Discourse Theory of Law and Democracy (Studies in contemporary German social thought). Cambridge, MA: Polity Press.

> Habermas, Jürgen (1990) Moral Consciousness and Communicative Action. Cambridge, MA: Polity Press.

>Hendriks, Caroline M., Dryzek, John S. and Hunold, Chistian (2007) Turning Up the Heat: Partisanship in Deliberative Innovation. Political Studies 55: 362-383. DOI: 10.1111/j.1467-9248.2007.00667.x.

>Kies, Raphaël (2010) Promises and Limits of Web-deliberation. New York, NY: Palgrave McMillan. DOI: $10.1057 / 9780230106376$.

>Klinger, Ulrike and Russmann, Uta (2015) The Sociodemographics of Political Deliberation: Measuring Online Quality in Different Users Groups. Communications, The European Journal of Communication Research 40 (4): 471-484. DOI: 10.1515/commun-2015-0017.

$>$ Klinger, Ulrike and Russmann, Uta (2014) Measuring Online Deliberation in Local Politics: An Empirical Analysis of the 2011 Zurich City Debate. International Journal of E-Politics 5 (1): 61-77. DOI: 10.4018/ijep.2014010104.

>Plaza Podemos (2015a) Propuesta de Renta Básica. RBCl del Círculo Renta Básica. [Basic Income proposal. RBCl from the Basic Income Circle]. http://www.reddit.com/r/podemos/ comments/2uz9mg/propuesta_de_renta_b\%C3\%A1sica_rbci_del_c\%C3\%ADrculo_renta/. (02.11.2016).

>Plaza Podemos (2015b) Iniciativa Ciudadana para mejorar el sistema de censo y potenciar la participación real en Podemos. [Citizen Initiative to improve the registration system and foster real participation in Podemos]. https://www.reddit.com/r/podemos/comments/31rg40/iniciativa_ ciudadana_para_mejorar_el_sistema_de/ (02.11.2016).

$>$ Podemos (2014) Principios organizativos. [Organizational Principles]. https://web-podemos. s3.amazonaws.com/wordpress/wp-content/uploads/2014/11/documento_organizativo_alta_03. pdf (19.02.2016).

>Steenberger, Marco R., Bächtiger, André, Spörndli, Markus and Steiner, Jürg (2003) Measuring Political Deliberation: A Discourse Quality Index. Comparative European Politics 1: 21-48. DOI: 10.1057/palgrave.cep.6110002.

>Steiner, Jürg (2012) The Foundations of Deliberative Democracy. Empirical Research and Normative Implications. Cambridge: Cambridge University Press. DOI: 10.1017/CBO9781139057486.

$>$ Strandberg, Kim and Berg, Janne (2013) Online Newspapers' Readers' Comments - Democratic Conversation Platforms or Virtual Soapboxes?. Comunicaçao e Sociedade 23: 132-152.

>Stromer-Galley, Jennifer (2007) Measuring Deliberation's Content: A Coding Scheme. Journal of Public Deliberation 3 (1). http://www.publicdeliberation.net/jpd/vol3/iss1/art12 (02.11.2016). $>$ Wessler, Hartmut (2008) Investigating Deliberativeness Comparatively. Political Communication 25 (1): 1-22. DOI: 10.1080/10584600701807752.

>Zhou, Xiang, Chan, Yuen-Ying and Peng, Zhen-Mei (2008) Deliberativeness of Online Political Discussion. Journalism Studies 9 (5): 759-770. DOI: 10.1080/14616700802207771. 


\section{OD PROTESTA DO POLITIČKIH STRANAKA: ONLINE DELIBERACIJA U NOVONASTALIM STRANKAMA U ŠPANJOLSKOJ}

\section{Rosa Borge Bravo :: Eduardo Santamarina Sáez}

SAŽETAK Nove stranke, koje su se pojavile nakon pokreta 15-M te kao odgovor na mjere štednje u Španjolskoj, žele se razvijati kao stranke otvorene za sudjelovanje i deliberaciju svih građana. U kojoj se mjeri ostvaruju ti ideali? Ciljje ovog članka opisati ivrednovati procese online deliberacije dviju najvažnijih stranaka u Španjolskoj, Podemos i Barcelona En Comú, na temelju uobičajenih kriterija u literaturi kojima se mjeri online deliberacija. Konkretno, analizirali smo dva prijedloga o kojima se najviše glasovalo na online platformi Plaza Podemos te online razvoj izbornog programa stranke Barcelona En Comú. Provedena je analiza sadržaja 713 objava s online platforme Plaza Podemos i 563 objave koje se tiču izbornog programa stranke Barcelona En Comú. Obje platforme posjeduju strukturne i tehničke kriterije za poticanje deliberacije, ali je vanjski utjecaj vidljiv samo u slučaju stranke Barcelona En Comú. Kvaliteta deliberativne komunikacije je dobra, ali kriteriji refleksivnosti, inkluzije i pluralnosti nisu zadovoljeni.

KLJUČNE RIJEČI

ONLINE DELIBERACIJA, DELIBERATIVNI KRITERIJI, 15-M, PODEMOS, BARCELONA EN COMÚ, ŠPANJOLSKA

Bilješka o autorima

Rosa Borge Bravo :: Faculty of Law and Political Science, Open University of Catalonia, Barcelona, Španjolska :: rborge@uoc.edu

Eduardo Santamarina Sáez :: nezavisni istraživač, Barcelona, Španjolska :: esantamarina@gmail.com 